\title{
AN ANALYSIS OF COHESION ON WRITING COMPARATIVE PARAGRAPH OF ENGLISH DEPARTMENT STUDENTS UNIVERSITAS RIAU KEPULAUAN IN THE ACADEMIC YEARS OF 2015/2016
}

\author{
Desi Surlitasari Dewi \\ Dosen Tetap Pendidikan Bahasa Inggris \\ Belldaisy46@gmail.com
}

\begin{abstract}
The objective of the research was to answer the research question which was to analyze grammatical cohesion and lexical cohesion of comparative paragraph produced by third semester students of English Department Universitas Riau Kepulauan. The research was conducted in three months starting from observing the sample to making report. This research was held on third semester students of English Department Universitas Riau Kepulauan in academic year 2015/2016. The research method used was qualitative study. The subject of the research was third semester of English Department Universitas Riau Kepulauan. There were several techniques to collect the data that was used in conducting a research, namely observation, questionnaire, interview, and test. In this research, the researcher conducted a writing test to get the data. In analyzing data, they were identified and classified in the appropriate headings on the cohesion analysis sheet. Then, it is classified into sentences for Grammatical and Lexical Cohesion analyzing process and interpreting each student's writing task.
\end{abstract}

\section{Keywords: Cohesion Analysis, Grammatical Cohesion, Lexical Cohesion,} Writing, Comparative Paragraph

\section{INTRODUCTION}

In learning English as foreign language, there are four basic skills that must be achieved, namely listening and reading as receptive skills, speaking and writing as productive skill. As a productive skill, writing is essential to be required by the learners since this skill is a form of thinking through writing. It means that the learners will be able to express their ideas to other people in written forms. Relating to the teaching of English writing, in the classroom, writing is the one of the four language skill besides speaking, listening, and reading which is considered to be a fundamental skill so that student need to learn it. It can be also said that writing is an important language skill because it is a productive skill that shows how skilful the students is in using the language and discovers the talented subtends in this field. In addition writing is away through which a students can express his/her ideas or thought on the paper. With the 
awareness of these necessities, writing is getting more and more attention in English language teaching in Indonesian context. The main focus of the teaching of the writing is to developed ability in creating good writing.

Beside that writing as one of the four skills in English is considered as the most difficult and most challenging skill compared to the other skill either for most students or even for the teacher. There are many cases in which both teacher and students have difficulties in producing a good writing. The difficulties are not only in generating and organizing ideas but also in translating these ideas into readable text. A text must have a texture that wholly proper to express the feature or property of being a text. It is what holds the sentences of a text together to make them unity. In binding sentences they need tie that is commonly called cohesive ties.

Halliday and Hasan (1976: 6) stated that there are two types of cohesion, namely: grammatical cohesion and lexical cohesion. In grammatical cohesion, the relationship between and within a text is signaled by means of grammatical elements. This includes reference, substitution, ellipsis, and conjunctions. Meanwhile, lexical cohesion is signaled by means of lexical of elements or vocabularies. It consists of reiteration and collocation. To provide a frame work for studying and analyzing the cohesion of writing or a text, the five types of cohesive devices namely reference, substitution, ellipsis, conjunction and lexical cohesion are used. It can make a text an efficient means of understanding and help the reader create meaningful semantic unit of the text for textual interpretation.

Based on the explanation above and with the purpose of improving the quality of teaching writing and improving the student's skill in writing a good text, it is necessary to conduct a study to analyze cohesiveness of the student's writing. Analyzing the student's problems in using cohesive devices has been seen as related to student's difficulty in producing a good text. Therefore, researcher will conduct research on student's problems in using cohesive devices in producing a good text entitled "An Analysis of Cohesion on Writing Comparative Paragraph of English Department Students, Universitas Riau Kepulauan in the academic years of 2015/2016”. 


\section{RESEARCH METHODOLOGY}

In this research, the research used a descriptive analysis with qualitative method. According to Riduan and Sunarto (2009) stated that descriptive analysis is an analysis which is describing a data individually or group. By conducting of the kind of the research, the researcher was going to analyze of the cohesion on student's writing assignment in third semester final writing examination. This research was a descriptive research, because it aims to describe things as the way it is and also to analyze the interrelationship of the data.

The subject of this study was the third semester students of English Department Universitas Riau Kepulauan. The total numbers of student as the subject of the study was 20 students. The research was conducted from December 2015 to February 2016. This study mainly focused on the analysis of cohesion of writing task produced by students. According to Halliday and Hasan (1976), to analyze cohesion of a text the unit of the analysis is sentence. The procedure of data collections are as follows:

1. Collecting the student's writing task as the object of the study.

2. Typing the student's text by arranging the number of sentences the students produced. It will be done in order it will be easier to analyze the students writing task.

3. The data of the study will be analyzed by focusing on cohesive devices achievement, the way the students organize their writing.

Each student's writing will be analyzed in terms of cohesive devices they used. After collecting data of the research, so they will analyze by using following steps:

1. Cohesive devices will be identified and classified in the appropriate headings on the cohesion analysis sheet.

2. To categorize whether or not comparative paragraph are written cohesively, the writer used certain criterion based on Halliday and Hasan.

3. Interpreting the result 
It was a process of interpreting the findings by consulting it to the theories. The result of recount texts analysis would be interpreted based on the number of grammatical and lexical cohesive devices. The level cohesiveness of recount texts would be clear after the writer did the interpretation.

\section{FINDINGS AND DISCUSSION}

In analyzing the data, the writer used Halliday and Hasan theory. Halliday and Hasan divided cohesion into five types; those are reference, substitution, ellipsis, conjunction and lexical cohesion. Therefore, the writer classified the data according to the kinds of cohesive types.

\section{Grammatical Cohesion}

Grammatical cohesion consists of four types. They are reference, ellipsis and conjunction. Reference is the act of referring to a proceeding of following element, deals with a semantic relationship. Meanwhile, Substitution and ellipsis; can be thought of in simplest terms as processes within the text; substitution as the replacement of one item by another, and ellipsis as the omission of an item. Conjunction refers broad to the combining of any two textual elements. The following the further explanation.

\section{a. Reference}

Reference is systems which introduce and track the identity of participants through text. There are three types of reference. They are personal reference,demonstrative reference and comparative reference. Based on this criterion all of the student's writing was created through the use of reference. In terms reference there was only one kind of reference that mostly use in their writings. It was personal reference. Personal pronoun as the personal reference categories was more tended used in the text. The findings implied that the students are more familiar in using personal references those other references. It was possible caused by the kinds of personal references are more than others so their occurrence was more than others. The frequency of occurrence could be caused by the frequency 
of use in daily actives. It could be both students and teachers use this reference more frequently than others. There is also possibility that in teaching and learning process this kind of reference get more attention than other references. The lowest in frequency was demonstrative reference. The possible causes were this kind reference is too complicated to learn so the references get less attention by both teachers and students. Based on this criterion, it can be seen and conclude that almost all of the students were doing good in using the reference in their paragraph.

b. Substitution

Substitution might be understood as the replacement of one item by another whereas the substitute item has the same function as that for which it substitutes. Substitution is a wording rather than in the meaning. There are three types of substitution; they are nominal, verbal, and clausal substitution. Based on this criterion, no one of the students occured substitution on their writing texts. It might be they did not understand or face difficulties to apply substitution on their writing. The substitution is identified by using the words "one, ones, or same". The substitution always had function as head of nominal group.

c. Ellipsis

Ellipsis is describes as a form of substitution in which the original item is replaced by zero. Ellipsis occurs when some essential structural is omitted from a sentence or clause and can only be recovered by referring to an element in the preceding text. Based on this criterion the reseracher found from the 15 students, there are only 12 students contains of ellipsisis. It was good since they understand to create effective sentence in their text.

d. Conjunction

Conjunction differs from reference, substitution and ellipsis in that it is not a device for reminding the reader of previously mentioned entities, actions and states of affairs. In other words, it is not what linguists call an anaphoric relation. However, it is a cohesive device because it signals relationships that can only be fully understood through reference to other 
parts of text. There are four different types of conjunction, they are: temporality, causality, addition and adversity. Based on this criterion the researcher found all of the students used conjuction in their text. From the data analysis the researcher found that they are good since their text contained conjuction.

\section{Lexical Cohesion}

Lexical cohesion refers to relationship between and among words in a text. Lexical cohesion is primarily related to field. Lexical cohesion occurs when two words in a text are semantically related in some way; they are related in terms of their meaning. There are two major categories of lexical cohesion are reiteration and collocation. Based on this creterion, all of the students writing text were built up by repetition. It was signaled by the repetition of some vocabularies used in their text. It was not effective enough since there is another option for the student as their reference when they are building sentence by sentence in the text namely use the synonym, hyponym or general words.

\section{CONCLUSION AND SUGGESTION}

Reflecting on the data analysis, it can be tentatively concluded that the writing text are written cohesively since the kinds of both grammatical and lexical cohesion are applied in those texts. Reference, ellipsis, conjunction and lexical cohesion (reiteration and collocation) are used by the students in the texts, therefore cohesive texts are established. From the data analysis and description that was interpreted in the previous chapter, the dominan cohesion was lexical cohesion in each students writing text. It can be seen from the percentage among gramatical and lexical cohesion. Student used repetition of vocabulary to build up sentence by sentence in their text. For the grammatical cohesion we can concluded that reference was dominant. Next is Conjunction and Ellipsis. Conjunction types they used were additive, adversative and temporal conjuction. Ellipsis cohesion which occured were verbal and nominal ellipsis. 
Based on the conclusion that had been explained above, the researcher needs to deliver some suggestions that are hopefully useful for the English teacher, students, reader and the next researcher as follows:

1. Practices in writing is in demand since the goal is to make the students able to write well in academic context.

2. It needs more attention related to how the students can compose or produce a cohesive and coherent text so all the message can be conveyed to the readers well.

\section{References}

Almaden, Daisy O. 2006. An analysis of the Topical Structure of Paragraphs Written by Filipino Students. The Asia-Pacific Education Research, 15(1), 127-153. December 2006. Download on April 17, 2014 http://www.dlsu.edu.ph/research/journals/tapers/pdf/200612/ALMADEN.pd $\underline{f}$

Hogue, Ann. 1996. First Step in Academic Writing. New York: Addison-Wesley

Halliday, M. A. K \& Hasan, Ruqaiya. 1976. Cohesion in English. London: Longman.

Irwin, Weiser. Linguistics: Encyclopedia of Rhetoric and Composition, ed. by Theresa Enos. Taylor \& Francis, 1996. Retrieved on April 10, 2014 http://grammar.about.com/od/c/g/cohesionterm.htm

Kilborn, Judith and Nathan, Kries. 1995. Cohesion: Using Repetition and Reference Words to Emphasize Key Ideas in Your Writing. Retrieved on April 10, 2014 http://leo.stcloudstate.edu/style/cohesion/html

Mawardi. 2011. An Analysis of the Cohesion and Coherence of the Students Narrative Writing in the English Language Education Department of Nahdlatul Wathan University Mataram: Unpublished Thesis. Undiksha

Oshima, Alice and Houge. 1983. Writing Academic English Writing Sentence and Structure. New York : Addison-Wesley Publishing Company

Riduan \& Sunarto, H. 2009. Pengantar Statistika. Bandung: Alfabeta

Zemach E Dorothy \& Lisa A Rumisek. 2008. Academic Writing. Macmillan: Universida De Sevilla 